\title{
Care Practice and Health Level of Elderly in Care Centre: Enhance Digital Lifestyle
}

\author{
Siti Nur Hadis A Rahman, Mastura Boharib, Muhammad Talhah Ajmain@ Jima'ain, Ahmad \\ Marzuki Mohamad, Aminudin Hehsan, Arieff Salleh Rosman, Nasrul Hisyam Nor Muhamad, \\ Zulkiflee Haron
}

\begin{abstract}
One of the issues faced by the senior citizens is inherited from the society's lifestyle which is less active physically, or not active at all. Retirement causes the problems amongst senior citizen more notable as it makes them not physically active anymore. Lifestyle is important in going through their daily life from health aspects, shelter, social life and many more. The aim of this research is focused on the founding of senior citizens' lifestyle in order to identify their lifestyle, their care practices on their health, and their overall health level as well as views on elderly care center. This research used qualitative and quantitative methodology by distributing questionnaire forms and interviews with a few of respondents in the elderly care center. In summary, these results show that 73.3 percent of respondents have decent health level, but 26.7 percent of respondents have health issues. This research also found that 93.4 percent of the senior citizens prefer to live in an elderly care center compared to living with their own family. Researchers have found that exercises and physical activities can lead to an increase of senior citizens' health level for those who aged 70 and above.
\end{abstract}

Keywords: Care Practices; Health; Elderly; Lifestyle

\section{INTRODUCTION}

Senior citizens or elderly people refer to individuals who are aged 60 and above. Those who are referred as senior citizens continues to rise ${ }^{[1]}$. The categorization of senior citizens to be 60 years old and above is lower than the criteria set by the World Health Organisation (WHO). WHO defines senior citizens or elderly people as individuals who are aged 65 and above. There have been some changes in humans and structures of community support system. Those changes include the increase in individual lifespans due to a better quality in food intake, better treatment methodology for

Revised Manuscript Received on September 22, 2019

Siti Nur Hadis A Rahman, Islamic Civilisation Academy, Universiti Teknologi Malaysia.

Mastura Bohari, Islamic Civilisation Academy, Universiti Teknologi Malaysia.

Muhammad Talhah Ajmain @ Jima'ain, Islamic Civilisation Academy, Universiti Teknologi Malaysia.

Ahmad Marzuki Mohamad, Islamic Civilisation Academy, Universiti Teknologi Malaysia.

Aminudin Hehsan, Senior Lecturer, Centre of Research for Fiqh Science and Technology (CFiRST), Universiti Teknologi Malaysia. ahehsan@utm.my Arieff Salleh Rosman, Centre of Research for Figh Science and Technology (CFiRST), Universiti Teknologi Malaysia

Nasrul Hisyam Nor Muhamad, Centre of Research for Figh Science and Technology (CFiRST), Universiti Teknologi Malaysia

Zulkiflee Haron, Centre of Research for Fiqh Science and Technology (CFiRST), Universiti Teknologi Malaysia. patients, technology advancement in healthcare and so many more. Aging process of citizens affect all life aspects, inclusive of individuals, communities, and the country. The life situations at old age depend on the life journey and planning from the start. The Ministry of Women, Family and Community Development (MWFCD) has set a number of strategies and objectives through National Older Persons Policy (January 2011). One of the objectives aims to encourage the preparations of certain facilities to ensure optimal senior citizens' care and protection towards their lives' prosperity. The implementation of these services is focused on care, protection and rehabilitation for senior citizens, families, and paupers (Paupers Policy 1977) which is in line with National Older Persons Policy 1995 and Older Persons Action Plan $1999^{[2]}$.

\section{A. Research Objectives}

- To identify a healthy lifestyle amongst senior citizens.

- To identify the elderly view of senior citizens' accommodations.

\section{B. Problem Statement}

The populations of senior citizens are increasing significantly in the world, including in Malaysia and they are facing multiple challenges in continuing their daily lives. Research on lifestyle is paramount in determining senior citizens' well-being specifically on emotions and health The issue of not eating a balanced diet has been the topic of discussion in the communities in our country. Health issues such as heart attacks, diabetes, and high blood pressures can be traced through someone's dietary habits which have been practiced since they were young [3]. According to Sanmargaraja \& Wee, (2013) in her research, a small group of respondents stated that the management does not focus on the occupants' needs in the government-organized elderly care centers. Not practicing a healthy lifestyle has become one of the problems amongst the elderly. This is due to the lack of physical activities and unfavourable lifestyles. In accordance with issues and statements above, it is imperative to realise that healthy lifestyles, as well as balanced dietary habits, are crucial amongst senior citizens. 


\section{Care Practice and Health Level of Elderly in Care Centre: Enhance Digital Lifestyle}

\section{LITERATURE REVIEW}

Senior citizens will undergo physical changes such as postures, ways of walking, skin conditions, hearing and sight ${ }^{[5]}$. A healthy lifestyle has to be practised by every individual regardless of age. A healthy lifestyle is defined as continuous daily activities that are practised by individuals to increase their individual health condition and prosperity ${ }^{[6]}$. A healthy lifestyle will increase one's lifespan. Those who practise a good and healthy lifestyle such as eating healthy, taking care of self-cleanliness and doing beneficial activities for themselves, have a high probability of living longer. The health needs for senior citizens are fulfilled through a network of hospitals and government healthcare centers throughout the country. However, specific facilities or experts' services for senior citizens' healthcare are still insufficient. Most of the healthcare services facilities for this group of people are provided in the form of nonstructural and general aid. Aside from the government sectors, the role of care, protection and social safety of this Country's senior citizens are within the responsibilities of private sectors, non-government organisation and many more. In that particular case, they assisted the government in organising public programs that were structured beforehand to fulfill the ever-increasing senior citizens' needs. Each development activity that was structured and implemented gave a direct impact on the increase of life quality for all layers of society. The quality of life concept is very broad and dynamic, inclusive of culture, health, social and environment. A better life quality will give a positive impact to all individuals in increasing their life's prosperity and thus preventing oneself from multiple diseases and complications ${ }^{[7]}$.

Nevertheless, from a study conducted Omar et al., (2011) it was found that around $98 \%$ of the respondents had health issues in the care centers. Moreover majority of the senior citizens have multiple health complication histories such as diabetes, cardiovascular issues, high blood pressure, stroke and other issues such as reduced sight, the ability of hearing and amnesia. Salleh (2013) mentioned that malnutrition is affected by a number of social and health factors. This discovery emphasises on the importance of joint efforts from all sectors or parties in successfully implementing food intervention program. However, Stocks et al., (2019) showed the ASPREE participants 'healthy' profile. ASPREE is a placebo-controlled trial involving 19.114 multicentres individuals 'healthy'. Not surprisingly, more than half of ASPREE participants run at least 30 minutes a day. Physical training was found to be useful for improving the physiological parameters in the elderly, reduce morbidity and improve quality of life related to health (HRQOL).

There has also been a demand in increasing the effort on empowering the healthcare professionals, volunteers, community leaders, senior citizens' caretakers as well as the senior citizens themselves on the importance of a healthy diet at old age, dietary habits and healthy lifestyles and encouragement of healthy aging processes. Supports from Non-Government Organizations (NGO) and volunteers in implementing food aid program and holding social activities for senior citizens are crucial and priceless. Results from the research conducted by Harun et al., (2018) showed that from four life quality domains which are physical, psychological, social and environment, physical domain was the main component that contributed to the decrease of senior citizens' life quality which was affected by diabetes. Correspondingly, a low level of education affects the knowledge and awareness of healthy lifestyles such as exercising and other physical activities that have known to affect the life quality of diabetes patients ${ }^{[11]}$. Practicing a healthy lifestyle in their middle stage of life could guarantee a healthy life pattern in their later life as well as enabling them to continue their healthy social activities.

\section{Methodology/Materials}

This research is focused on the lifestyle of senior citizens in Sabak Bernam, Selangor. There were 30 respondents, chosen at random, consist of the occupants from those elderly care centers to identify their lifestyle. The structure of this study comprises of literature studies, observations, extended interviews, and questionnaire forms. Questionnaire forms were distributed to the respondents to identify the senior citizens' lifestyle practices in the chosen elderly care centers.

\section{RESUltS AND FINDINGS}

Table 1 shows the respondents' background based on age, number of children, status and health condition. This research's analysis is represented by $96.8 \%$ of women senior citizens respondents.

Table 1. Respondents' Demographic Information

\begin{tabular}{cccc}
\hline Item & Respondents & Numbers & Percentage \\
\hline \multirow{4}{*}{ Age } & $60-65$ & 5 & $16.7 \%$ \\
& $66-70$ & 21 & $70 \%$ \\
& $71-75$ & 3 & 10 \\
Number of & 76 and above & 1 & 3.3 \\
Children & $2-3$ & 18 & $58.1 \%$ \\
& $4-5$ & 2 & $6.5 \%$ \\
& Others & 5 & $16.1 \%$ \\
Status & Married & 13 & $12.9 \%$ \\
& Single & 12 & $43.3 \%$ \\
Health & Single Mother & 5 & $40 \%$ \\
Condition & Not Healthy & & $16.7 \%$ \\
Total & & 22 & $73.3 \%$ \\
\hline
\end{tabular}

\section{A. Health Lifestyle Among Senior Citizens}

A healthy lifestyle can be defined as consistent daily activities by individuals. Responsibilities towards health, eating habits and exercises determine a healthy lifestyle. Respondents were also asked to give their opinions on their health condition, whether they were healthy or not healthy.

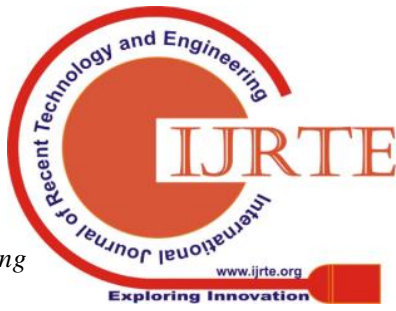


As can be seen from the table (above), 73.3\% said that they were healthy while $26.7 \%$ mentioned that they had some health complications. $93.3 \%$ of the respondents undergo medical checkup annually while the rest do not. Majority of the respondents do their medical checkup at government clinics that are nearby their accommodations. Some of their main reasons for not doing their medical checkup were because they were still healthy, they were anxious to know their health conditions after doing the medical checkup and they chose to receive their treatments in a traditional manner. $26.7 \%$ of the respondents who had health issues are suffering from high blood pressure, diabetes and other illness such as knee and joint issues and others. Physical exercises are crucial for individuals, especially for senior citizens. $96.7 \%$ of the respondents are active in physical exercises daily or at least once a week. The rest, which is $3.3 \%$ do not exercise at all. $96.7 \%$ of respondents agreed that having a healthy eating habit helps in reducing the risks of serious illness. Aside from that, an organised daily dietary schedule is crucial for good health. Most of the respondents are taking supplements aside from listening to doctors' advice.

\section{B. Observations Towards Senior Citizens' Accommodations}

This study found that $93.4 \%$ of senior citizens prefer to live in elderly care centers compared to their own family's houses. This is an unexpected result outcome. Moreover, $56.7 \%$ of the respondents did not agree with the notion that they were forced to live in elderly care centers. Majority of the respondents were very much content with the facilities that are provided in those elderly care centers such as accommodations, donations, the safety of the bathrooms, kitchens, arrangements of furniture and other reasons. These findings prove that Malaysians are not neglecting both of their parents since they always visit their parents, check their wellbeing and help them financially.

\section{ENHANCE Digital LIFESTYLE AMONGST ELDERLY IN CARe Centers}

Senior citizens and the development of communication technology is not a new issue in the study of social sciences and humanities. Several studies have revealed that the implications of communication technology are often focused on adolescents or youth, but senior citizens are also associated with the phenomena as they are also in the environment of digital communication networks that occur today. However Zaiamri \& Sariyati, (2016) published a paper in which they described that the challenges faced by senior citizens in terms of the use of new media were due to the barrier of use such as being unable to adapt and mistrust to the function of this technology medium. Information and communication technology (ICT) have revolutionized the digital lifestyle of the younger generation but not so to the elderly. This is because most of them find it difficult to handle existing ICT devices.

The systematic study was reported by Thivenesh et al., (2017) to facilitate the use of technology to the elderly, the findings of this study suggest that Near Field Communication (NFC) to provide an experience to the old community. They can easily Skype calls, view favorite photo slideshows, watch videos and monitor IP surveillance cameras. A prototype of NFC assistive button was implemented and tested by a group of participants staying at elderly care centers. Initial responses from the participants indicate that it was easy to use, useful and they intend to use it in the future. It cannot be denied that today's elderly is more knowledgeable compared to the previous generations. In the past, the senior citizens were often seen to be weak and needed the protection of the community. However, these days, they have proven that they can still contribute in many ways for the benefits of society and the country. However, the elderly should not live alone. We often forget that the elderly may also struggle with loneliness, to enhance their quality of life might help by making daily routines easier with activated technologies such as app usage, phone, tablet and many others.

According to recent reports by Kim et al., (2019) 247 Korean Americans who suffer from pre-diabetes or diabetes enrolled in a hybrid model self-help intervention program (hSHIP), and 215 of whom completed the intervention and 630 of them through counseling sessions. Although the majority of participants are older adults, they can receive intervention components using simple technology, where the intervention component is coordinated with bilingual and also Korean translation. It shows the respondents receive a digital touch, as long as they are helped by an important human touch. As explained in the introduction, it is clear that technological advances in healthcare are beneficial to all users.

\section{Conclusion}

As was mentioned in the previous chapter, the study aims to identify the elderly lifestyle, especially from health, eating habits, and their lifestyle in care centers. The findings found that respondents prefer to live in elderly care centers instead of living in their own homes. This interpretation differs from other reseachers who argue that respondents prefer to live in their own homes because of safety reasons ${ }^{[15]}$. The Australian sample included a higher proportion of elderly individuals living at home with family or friends $(67.7 \%)$ compared with the USA sample $(60.8 \%)^{[9]}$. Overall, the study found that the percentage of respondents who did not have chronic health problems was high and not worrying. However, high blood pressure and joint pain are the most common illness amongst the respondents. Respondents need to change their lifestyle to reduce this problem especially in the context of age-appropriate food intake and health. Moreover, healthcare systems for senior citizens at local clinics have to be expanded into providing transportation services, hearing or sight aid devices and dental care services to increase the life quality of these elderly group of people. As a result of interviews by researchers the majority of respondents do not have a smartphone and their lifestyles

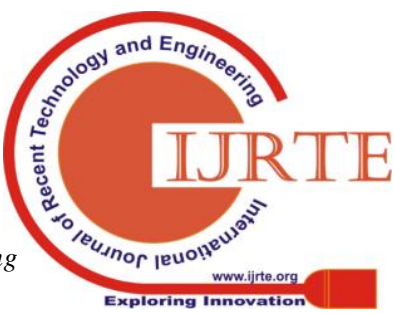




\section{Care Practice and Health Level of Elderly in Care Centre: Enhance Digital Lifestyle}

are more focused on community activities such as mutual cooperation and listening to lectures. This study was only conducted on 30 elderly people, future research should expand the study to provide findings that will be clearer and more comprehensive advantages of using technology in the elderly in Malaysia.

\section{ACKNOWLEDGEMENTS}

The authors hereby acknowledge the Universiti Teknologi Malaysia for their financial support through the Grant no.Q.J130000.2533.19H96

\section{REFERENCES}

[1] Md Nawi NH, Megat Ahmad PHMAH, A. Malek MD, Cosmas G, Ibrahim HI, Voo P. Pengaruh Sokongan Emosi dan Sosial ke atas Hubungan Intergenerasi dalam Penjagaan Warga Tua Pelbagai Etnik. Sains Humanika 2019;11(2):27-34.

[2] KPWKM. Dasar Kesihatan Warga Emas Negara. Kementeri Pembang Wanita, Kel dan Masy 2016;

[3] Salleh N. Kesedaran Terhadap Amalan Pemakanan Seimbang Dalam Kalangan Orang Dewasa: Satu Tinjauan. Univ. Tun Hussein Onn2013;

[4] Sanmargaraja S, Wee ST. Pandangan warga tua di rumah warga tua:kajian kes di bandaraya ipoh dan johor bahru. Persidang Kebangs Geogr dan Alam Sekitar Kali Ke 4 2013;143-151.

[5] Husin SZ, Alavi K. Kerja Sosial Di Hospital : Meneroka Pengabaian. 2016;11(2):462-484.

[6] Krishnan M, Rahim SA. Hubungkait Komunikasi Kesihatan. Malaysian J Commun 2014;30(1):147-176.

[7] Ngah FH, Lian DKC. Kualiti Hidup dan Aktiviti Fizikal Warga Emas (Quality of Life and Phys(2017). Kualiti Hidup dan Aktiviti Fizikal Warga Emas (Quality of Life and Physical Activity in Elderly). Geografia - Malaysian Journal of Society and Space, 13(2).ical Activity in Eld. Geogr - Malaysian J Soc Sp 2017;13(2):44-53.

[8] Omar R, Knight VF, Saat NZM, Kamaralzaman S, Alwi SNS. Gangguan Penglihatan dan Kualiti Hidup Warga Emas di Pusat Jagaan. J Sains Kesihat Malaysia (Malaysian J Heal Sci 2011;9(1):23-27.

[9] Stocks NP, González-Chica DA, Woods RL, Lockery JE, Wolfe RSJ, Murray AM, et al. Quality of Life for 19,114 participants in the ASPREE (ASPirin in Reducing Events in the Elderly) study and their association with sociodemographic and modifiable lifestyle risk factors. Qual Life Res 2019;28(4):935-946.

[10] Harun D, Baharin NH, Razaob NA, Sakian NIM, Johari N, Farah N. Tahap Kefungsian Aktiviti Kehidupan Harian Asas dan Kualiti Hidup Warga Tua Penghidap Diabetes. J Sains Kesihat Malaysia (Malaysian J Heal Sci 2018;195-202.

[11] J.I. B, S. Z, M. W, B. N, S. H, N. P, et al. The impact of level of education on vascular events and mortality in patients with type 2 diabetes mellitus: Results from the ADVANCE study. Diabetes Res Clin Pract 2017;127:212-217.

[12] Zaiamri M, Sariyati A. Cabaran dan pengadaptasian warga emas dalam persekitaran jaringan digital. J Komun 2016;32(1):581-606.

[13] Thivenesh T, Heng CY, Cheong SN, Yap WJ, Ooi CP. Enhance digital lifestyle of elderly with near field communication assistive button. Adv Sci Lett 2017;23(6):5324-5328.

[14] Kim MT, Kim KB, Nguyen TH, Ko J, Zabora J, Jacobs E, et al. Motivating people to sustain healthy lifestyles using persuasive technology: A pilot study of Korean Americans with prediabetes and type 2 diabetes. Patient Educ Couns 2019;102(4):709-717.

[15] Ismail NSA, Abdullah N, Hassan K, Samsudin S, Zakuan UAA, Yusof $\mathrm{R}$, et al. Well-being among the elderly: Gender-based planning. Malaysian J Soc Sp 2018;13(3):75-85.

\section{AUTHORS PROFILE}

Siti Nur Hadis A Rahman, I am from Islamic Civilisation Academy, Universiti Teknologi Malaysia and my area of interest is social science

My name is Mastura Bohari, I am from Islamic Civilisation Academy, Universiti Teknologi Malaysia and my area of interest is social science

Muhammad Talhah Ajmain@ Jima'ain, I am affiliated with Islamic Civilisation Academy, Universiti Teknologi Malaysia.my area of interest is social sciences.
Ahmad Marzuki Mohamad, I am affiliated with Islamic Civilisation Academy, Universiti Teknologi Malaysia.and my area of ineterst is social sciences.

Aminudin Hehsan, I am working as Senior Lecturer, Centre of Research for Fiqh Science and Technology (CFiRST), Universiti Teknologi Malaysia.my area of interest is social sciences.

Arieff Salleh Rosman, i am affiliated with Centre of Research for Fiqh Science and Technology (CFiRST), Universiti Teknologi Malaysia. My area of research social science

Nasrul Hisyam Nor Muhamad, I am affiliated with Centre of Research for Fiqh Science and Technology (CFiRST), Universiti Teknologi Malaysia. My area of interest is social science.

My name is Zulkiflee Haron, I am from Centre of Research for Fiqh Science and Technology (CFiRST), Universiti Teknologi Malaysia.my area of interest is social sciences 